against crystallization by the strategic blockage of countless nuclei ... . and at once the concept becomes alive.

By comparison with what has gone before, the orthopædic contributions are rather lightweight, particularly that on non-union and delayed union. Problems of internal fixation of fractures might have deserved a special chapter, Charnley's work on the timing of operation being one important topic for discussion.

The production maintains the high standard associated with Butterworth's publications. Minor criticisms are that the lay-out of illustrations in Chapter 5 could be improved and the radiograph on page 220 , a difficult subject, does not show all that is intended.

This important book is essential reading for surgeons training in orthopæedics and traumatology, and for those purporting to teach them at undergraduate and postgraduate levels.

\section{On the Nature of Neoplasia in Man}

D. W. Smithers. Pp. i +176 . Edinburgh and London: E. \& S. Livingstone. 1964. 25s.

This volume is a collection of lectures delivered by Professor Smithers during the period 1952 to 1962 all devoted to discussions on the nature of the neoplastic change and the various factors influencing it, and giving the author's own views both on neoplasia and on other peoples views on the subject. In the foreword he states that these papers have already been criticized because they have appeared in the Medical Press but certainly that is no reason why they should not be published again for they form an intensely interesting review of all the current theories of neoplasia. His two main theses which recur frequently are that cancer research needs more scope for the testing of ideas and less waste of time and money on the collection of observations unrelated to these tests and the destruction of "cytologism"- a word coined by the author for any theory which regards the events of organismal life as the outcome of individual cell initiation.

These essays make fascinating reading. One could wish that the lecture on carcinoma of the breast was more up to date because many changes have taken place in our conception of breast cancer since 1952 but the whole contribution is a stimulating and very readable treatise on a subject of universal medical interest.

\section{Cellular Injury}

Ciba Foundation Symposium. Edited by A. V. S. DE ReuCK and Julie KNIGHT. Pp. xi +403 , illustrated. London: J. \& A. Churchill. 1964. 60s. This book gives an account of a small international symposium on cellular injury organised by the Ciba Foundation and held in July 1963 under the chairmanship of Sir Roy Cameron. In many respects this symposium is a sequel to one on lysosomes held a few months earlier by the Ciba Foundation.

The fifteen papers presented at the meeting cover a wide range of topics but they are all concerned with intracellular pathology and the recurrent theme is of attempts to identify specific biochemical lesions and to locate their site of action in particular components of the cell. One group of papers deals with cellular injury produced by exogenous factors such as alkylating agents, leucocidin, folic acid antagonists, corticosteroids and hepatotoxic agents. Many of the speakers mention the limitations of light microscopy and it is appropriate that four other papers are concerned with electron microscopy of damaged cells. There is an especially fascinating account of fine structural lesions induced by viruses. In a further group of papers several aspects of cell death are considered. These include a timely reminder to pathologists that they may still learn from a study of the normal and, in particular, that cell death is often a normal phenomen in development and in adult life. The final session was a general discussion in which de Duve summarizes the role of lysosomes in pathology and the other participants suggest lines for future research.

The work presented in this volume will appeal to all interested in the progress of pathology from a cellular to a molecular level. The content, editing and format of the book maintain the very high standard set by previous issues in the series of Ciba Foundation Symposia.

\section{Cell pH}

E. Edward Bittar, M.D. Pp. viii + 129, illustrated. London: Butterworths. 1964. 37s. 6d.

This is an odd little book which in the course of 121 pages covers the physical chemistry of hydrogen and the hydrogen ion, $\mathrm{pH}$, a fair amount of the biochemistry of cells, membranes and energy, some cytology, gastric secretion, muscle cell $\mathrm{pH}$ and ends with chapters suggesting that the most important disturbance in liver and renal failure is loss of control of cell $\mathrm{pH}$. The coverage is even more superficial than space permits and much of it is just theoryand name-dropping. The English is also very uneconomical. Bearing in mind the price, this book might be recommended as a quick aide-memoire and ready source of references for those familiar with the subject and they will pick up odd facts but nobody is likely to gain understanding from reading it.

\section{Medical Sociology and Cultural Anthropoolgy of} Sport and Physical Education

ERNST JoKL. Pp. viii +166 , illustrated. Springfield, Illinois: Charles C. Thomas. \$7.50.

The major work in this collection of three essays is on the medical sociology of sport, written in collaboration with colleagues from the Finnish Institute of Occupational Health. Perhaps its impetus derives from the attention drawn to the "alarming decline of youth fitness" in the U.S.A. by President Eisenhower and President Kennedy.

A statistical approach establishes the true contribution of the competing nations at the 15th Olympic Games in Helsinki 1952, from a consideration of total participation, the contribution per unit of population, and the points scored. Though perhaps insufficient account is taken of many variables, some interesting conclusions have been drawn.

Black athletes were found to have superior natural endowment, the yellow-brown races being intermediate, then the whites. Europe established its athletic dominance over the U.S.A. and U.S.S.R. when statistical allowance was made for population differences. Asia made a low total contribution, yet the conclusion is drawn that both this continent and Africa were destined to make increasing contributions to sport as they developed politically. 